\title{
The Role of Forensic Accounting Techniques in Reducing Cloud Based Accounting Risks in the Jordanian Five Stars Hotels
}

\author{
FIRAS HASHEM \\ Accounting Department Tafila Technical University \\ Tafila, JORDAN \\ firashashem@ttu.edu.jo
}

\begin{abstract}
The current study investigated the role of forensic accounting techniques in reducing Cloud Based Accounting risks in the Jordanian five stars hotels. The study population consisted of all accountants in Jordanian five stars hotels. Five stars hotels accountants located in Amman the capital were selected subjects. The total is (170) accountants. A random sample amounting 118 accountants were selected. 118 questionnaires were distributed and 96ones were collected. The study concluded that: There is a significant role of Forensic Accounting Techniques ((FPDDS), (FAIIS), (LMAS), (CARDR)) in reducing Cloud Based Accounting risks in the Jordanian five stars hotels. Despite the fact that nature of computer crime is increasing daily, so there is a need for different types of efforts, to be made on all levels of cloud investigations. And in the same time all legislations and codification related to computer crimes must be updated and reviewed from time to time to keep up with emerging technology.
\end{abstract}

Keywords: forensic accounting, cloud-based accounting risks, fraud prevention, forensic audit, litigation, computer assisted reviews and document reviews.

Received: July 25, 2020. Revised: January 6, 2021. Accepted: January 19, 2021. Published: February 4, 2021.

\section{Introduction}

\subsection{Introduce the Problem}

The accounting world has become a fast searching and quick looking to find solutions for the problems associated with accounting figures, manage business accounting to reduce time, costs, and the employees needed. If you have a device connected to an internet, then you will be able to access the accounting data to find automatically updated financial information and provide financial reporting in real-time.

Cloud computing is hastily evolving information technological know- how phenomenon and its use in criminal undertaking is likely to develop further. The definition, terminology, tools, standards, ethics and many special predominant components of this rising place have been as give up end result of this amplify

Cloud computing is first and fundamental a thought of distributed exchequer management and employment .NIST (National Institute of Standards and Technology) has defined cloud computing as a "model for enabling ubiquitous, convenient, on-demand network access to a shared pool of configurable computing sources (e.g., networks, servers, storage, applications, and services) that can be rapidly provisioned and released with minimal administration effort or service issuer interaction." (Mell
\& Grance, 2011).

It targets at providing handy endpoint get right of entry to machine while not requiring purchase of software, platform or physical network infrastructure, instead outsourcing them from $1 / 3$ parties. The arrangement may beneficially affect competitive advantage flexibility however it additionally brings about a variety of challenges. ( Mohanty \& Mishra,2017)

In order to cease any professional fraud and financial violations, corporations will do whatever it takes to maintain stability and safety as well as to assure financial numbers free from errors. While performing an audit may be a way of deterring fraud and error, the auditor is not and can't be held responsible for their banning (Sunday \& Eton, 2013).

The importance of forensic accounting has been increased in the recent decades due to the many financial problems, manipulated statements and fraudulent activities. In order to protect and save the stockholders' shares and the investors' savings, forensic accounting has become an important tool to act as a protective shield 


\subsection{Explore Importance of the Problem}

Cloud based accounting have been facing various types of risks. However, the most significant types of risks facing cloud computing are the security, transparency and control risk levels. Thus, that requires coming up with solutions that can reduce the latter risk levels. However, it should be noted that forensic accounting is considered one of those solutions.

Hence, the problem of the current study can be seen through seeking to provide answers for the following questions:

1) To what extent do the forensic accounting techniques reduce cloud based accounting risks in the Jordanian five stars hotels?

2) To what extent do the (FPDDS) (Fraud prevention, detection and deterrence skills) reduce (security, transparency and control risk levels) cloud based accounting in Jordanian five stars hotels?

3) To what extent do the (FAIIS) (Forensic audit, investigation, and interviewing skills) in reducing (security, transparency and control risk levels) in cloud based accounting in Jordanian five stars hotels?

4) To what extent do the (CARDR) (Computer assisted reviews and document reviews) in reducing (security, transparency and control risk levels) in cloud based accounting in Jordanian five stars hotels?

\subsection{Literature Review}

\subsubsection{Forensic Accounting Definition}

The American Institute of certified public Accounting (AICPA) defined forensic accountant as "The application of specialized knowledge and investigative skills possessed by CPA, to collect, analyze and evaluate evidential matter and to interpret and communicate findings in the courtroom, boardroom, or other legal administrative venue" (AICPA, Expert Witness, 2010, p6).. Forensic accounting is also defined as: "Popova et al., (2014), defines forensic accounting as" the process from the implementation of any fraud investigation to the formation of accounting records after the discovery that they have been manipulated"

Interest in forensic accounting increased after the economic collapses of various international economic organizations due to fraud, which increased judicial cases before courts and in the same time forensic accounting services is not limited on judicial authorities but it required for many parties such as banks, police, insurance companies, and governmental organizations. (Bhasin, 2013)

\subsubsection{Forensic Accounting Techniques for Fraud Detection:}

Forensic accounting has various techniques that are used in collecting information process for the purpose of carrying out the necessary analyzes to find out fraud practice,

1- Data mining:

This technique depends on trying to mine a large amount of data in search of any new hidden or unexpected patterns or information, and this technique is implemented through computer programs designed for this purpose.The data mining technology helps the forensic accountant in the investigation, but the investigation process is not completed through the computer screen only, but it requires reviewing documents, interviewing and other investigative work. In addition to the necessity to verify the accuracy of the data obtained and verify its completeness

2- Continuous control: it is considered as s one of forensic accounting techniques that are used to obtain evidence related to fraud. Continuous control processes are concentrated in audit departments, branches, customers and agency owners

3- Ratio analysis: Such technique is concerned with analyzing digital data ratios for the purpose of identifying evidence of fraud processes. (Jamil, 2012, p.13).

4- Benford's Law: It is one of the techniques of forensic accounting, and one of the important laws in mathematics and statistics that have been employed in auditing processes. When this law is used, it becomes possible to examine the quality and reliability of accounting numbers or data and identify anomalies thereof, in order to be able to usedorensic accounting techniques in disclosing accounting practices

5- Computer-assisted auditing tools: According to this technology, technology is used and employed to accomplish some auditing work that helps the forensic accountant to complete his task in a better, faster, and lower cost. The use of this technology requires the availability of all the necessary information for the process of auditing computer systems (Al-Khalidi, 2012, p. 309).

\subsubsection{Cloud computing Concept:}

Cloud computing is a" technology that depends on transferring processing, storage space and data of computer to the so-called the cloud, which is a server device that is accessed via the Internet, that is, it transformed information technology programs from products to services, it is also characterized by solving maintenance problem and development of programs for companies using them, Consequently, the efforts of beneficiaries are focused on using these services only" (Al- 
Shetty, 2013, p.9)

Microsoft has defined cloud computing as "providing computing services (servers, storage, databases, networks, software, analytics and more) over the Internet. Companies that provide these computing services are called cloud service providers and usually charge fees for cloud computing services on a cloud-based basis. Similar to the way in which a bill for water or electricity is billed at home .While IBM defined it as providing computing resources on demand (everything from applications to data centers) via the Internet and paying for the use of these resources .According (Thomas, et al 2013) Cloud computing is a specialized form of distributed computing that introduces utilization models for remotely provisioning scalable and measured resources

Muwwad,(2012) classified Cloud Computing services as:

A) Infrastructure as a Service (IaaS)

It is the basic or the bottom layer of cloud computing, it includes services such as storage, precautionary copies, disaster recovery, databases and security, such as Amazon Web Services, and it provides two types of services

1- Elastic Compute Cloud (EC2)

2- Simple Storage Service (S3).

B) Platform as a Service (PaaS)

It is the next level of the cloud, it is often used for organizations that develop or modify their software applications and the computing environment supports the processes of developing software as well as publishing and hosting it, usually arranged with a specific operating environment such as Windows or Linux.

C) Soft form as Service (PaaS)

It is the highest level in the cloud, where software or data applications are hosted on the Internet and perform a set of functions on them remotely. Examples include Drop Box and Google Docs

\subsubsection{Previous Studies}

Özcan, (2019) investigated the impact of forensic accounting on detection of financial information manipulation in the current business environment. The dynamics of forensic accounting are discussed. The methods used by forensic accountants to detect financial information manipulation are presented. The results of empirical analysis are expected to substantially contribute to the forensic accounting investigation. In designing forensic accounting investigation, forensic accountants should pay close attention distinct advantage of each model used in the detection of financial information manipulation. It is worth mentioning that financial information manipulation can be preventable. Strong corporate governance mechanisms and effective internal control systems should be established by firms to prevent financial information manipulation. Past experiences demonstrated that the judgmental knowledge of forensic accountants plays prominent roles in the detection of financial information manipulation. The present study aims to analyze the contributions of forensic accounting in detecting financial information manipulation. It appears that forensic accounting investigations will grab more attention in the general economic environment. Emmanuel \&Olajide (2019) examined the relevance of forensic accounting techniques in ensuring the integrity of the financial statements. The study adopts survey research method with the use of primary data and purposive random sampling techniques. The study sample consisted of 321 subjects. Nominal scale method was used in the demographic section while Likert scale was used in other sections of the questionnaire. The study concluded that forensic accounting techniques "FAT" (FPDDS, FAIIS, LMAS, and CARDR) have positive influence on the integrity of financial statements (IFS) of business organizations. Rihan (2019) study discussed the theoretical concepts behind cloud accounting and its

adoption in a developing country like Bangladesh. The study indicated that cloud accounting is more cost effective, secure and flexible and, provides larger storage compared to traditional accounting. The study provides a frame work that can be used for the adoption of cloud accounting in the business sector of Bangladesh. Salunkhe and Kelkar (2016) analyzed the scope of cloud computing in the education system. They found that almost $74 \%$ of sample subjects aware of the cloud computing concept and $45 \%$ of the research sample indicated that staff motivation is a major factor that may affect the adoption of cloud computing. Bechtel, (2013) explored challenges posed by cloud computing focusing. The study explored how cloud computing will impact the current tools, frameworks and procedures used or followed in forensic investigation suggested a framework for implementing cloud accounting in Bangladesh. They argued that four steps should be taken in consideration upon implementing cloud accounting, these steps include feasibility study, planning, implementation and renewal. Jones, et al. (2017) study aimed to investigate the implementation of cloud computing, whether within a framework or from the viewpoint of users in different companies, by studying three local government authorities in the United Kingdom. The study found various results that included major rewards such as improved information and management, flexibility in work practices, in addition to risks such as loss of control and lack of ownership of data on the part of organizations. Kinkela,( 2015) study analyzes the risks of 
cloud computing in an effort to identify best practices for implementing the use and regulation of the cloud computing within companies. The study shows that cloud computing promises to reduce the cost of efficiency for companies and specifically the accounting departments. The study demonstrated that cloud computing is now an acceptable part of the suite of technologies available to accountants. Emphasizing that cloud computing can provide efficiency and reduce costs, the study indicated that before using cloud technology, companies should understand the risks inherent in this new technology. By taking a systematic approach to avoiding risks, including setting effective cloud usage policies and a risk-response plan that enables companies to take advantage of this technology.

\subsection{State Hypotheses and Their Correspondence to Research Design}

Ho: There is no statistically significant role of Forensic Accounting Techniques in reducing Cloud Based Accounting risks in the Jordanian five stars hotels

Ho-1 There is no statistically significant role of (FPDDS) (Fraud prevention, detection and deterrence skills) in reducing (security, transparency and control risk levels) in cloud-based accounting in Jordanian five stars hotels

Ho-2 There is no statistically significant role of (FAIIS) (Forensic audit, investigation, and interviewing skills) in reducing (security, transparency and control risk levels) in cloud-based accounting in Jordanian five stars hotels.

Ho-3 There is no statistically significant role of (LMAS) (Litigation, mediation and arbitration skills) in reducing (security, transparency and control risk levels) in cloudbased accounting. in Jordanian five stars hotels

Ho-4 There is no statistically significant role of (CARDR) (Computer assisted reviews and document reviews) in reducing (security, transparency and control risk levels) in cloud-based accounting. in Jordanian five stars hotels. 2.

\section{Methodology:}

Descriptive analytical methodology is used to test The Role of Forensic Accounting Techniques in Reducing Cloud Based Accounting Risks in the Jordanian Five Stars Hotels.

\subsection{Population and Sampling}

Study population consisted of all accountants in Jordanian five stars hotels. Five stars hotels accountants located in Amman the capital were selected subjects. The total is (170) accountants. A random sample amounting 118 accountants were selected .118 questionnaires were distributed and 96 ones were collected

\subsection{Questionnaire}

A questionnaire was designed based on the previous literature. The questionnaire consists of three parts: the covering letter in which research objective were explained, subjects were asked to answer all questions accurately, and they were assured that their responses will be considered confidential and to be used for the purpose of the research only.

\subsection{Data collection methods}

Two data collection methods are available

2.3.1 Secondary data collection: Books, periodicals, journals, references and the internet were used for collecting the required data.

2.3.2 Primary data collection: the research used the questionnaire to collect the primary data

\subsection{Research Validity}

The questionnaire was subject to validation by number of university staff their comments and amendments were taken in consideration.

\subsection{Research Reliability}

Cronbach alpha was used to test the reliability of the questionnaire . it is found that alpha was (94.7) which is represented as an acceptable level of reliability. 


\subsection{Statistical Analysis Methods:}

Following statistical analysis were used:
2- Multiple regression analysis to test the hypotheses of the study

3- Reliability Test.

1- Descriptive statistics.

\section{Results}

Table (1)

Sample subject distribution according Demographic

\begin{tabular}{|l|l|l|l|}
\hline \multirow{4}{*}{ Age } & Option & Frequency & Percent \\
\cline { 2 - 4 } & Less than 25 years & 6 & 6.3 \\
\cline { 2 - 4 } & 25 to less than 35 & 19 & 19.8 \\
\cline { 2 - 4 } & 35 to less than45 & 36 & 37.5 \\
\cline { 2 - 4 } & $45+$ & 35 & 36.5 \\
\hline \multirow{5}{*}{ Educational Level } & Bachelor degree & 4 & 4.2 \\
\cline { 2 - 4 } & Master degree & 66 & 68.8 \\
\cline { 2 - 4 } & Ph.D. degree & 26 & 27.1 \\
\hline \multirow{5}{*}{ Experience } & Accounting & 78 & 81.3 \\
\cline { 2 - 4 } & Business administration & 18 & 18.8 \\
\hline \multirow{5}{*}{ Professional Certificate } & -5 years & 5 & 3.2 \\
\cline { 2 - 4 } & 5 to less than 10 years & 11 & 39.6 \\
\cline { 2 - 4 } & 10 to less than 15 years & 38 & 35.4 \\
\cline { 2 - 4 } & $15+$ & 42 & 15.6 \\
\cline { 2 - 4 } & JCPA & 34 & 49 \\
\cline { 2 - 4 } & CPA & 15 & 47 \\
\hline
\end{tabular}

Above table shows that $37.5 \%$ of the sample was between (35 to less than 45 years old), whereas, $68.8 \%$ of the sample had Master degree, $81.3 \%$ of them were specialized in accounting . $43.8 \%$ of the sample had experience for more than 15 years. Also $49 \%$ of the sample had CMA.

\subsection{Descriptive Statistics}


Table (2)

Means and standard deviation of the independent variables

\begin{tabular}{|l|l|l|l|l|}
\hline Variable & Mean & $\begin{array}{l}\text { Std. } \\
\text { Deviation }\end{array}$ & Rank & Level \\
\hline $\begin{array}{l}\text { (FPDDS) (Fraud prevention, detection } \\
\text { and deterrence skills) }\end{array}$ & 3.86 & .845 & 4 & High \\
\hline $\begin{array}{l}\text { (FAIIS) (Forensic audit, investigation, } \\
\text { and interviewing skills }\end{array}$ & 4.18 & .677 & 2 & High \\
\hline $\begin{array}{l}\text { of (LMAS) (Litigation, mediation and } \\
\text { arbitration skills) }\end{array}$ & 4.23 & .625 & 1 & High \\
\hline $\begin{array}{l}\text { (CARDR) (Computer assisted reviews } \\
\text { and document reviews) }\end{array}$ & 4.08 & $.63^{*}$ & 3 & High \\
\hline
\end{tabular}

**Prepared by researcher based on SPSS. outputs.

Table (2) indicated that the most important role for forensic accounting is of (LMAS) (Litigation, mediation and arbitration skills) since its mean is 4.23 while (FAIIS) (Forensic audit, investigation, and interviewing skills ranked the second with a mean 4.18, (CARDR) (Computer assisted reviews and document reviews) ranked the third mean 4.04 and finally FPDDS) (Fraud prevention, detection and deterrence skills) ranked the last. It is worth to mention that all variable have high role in detecting fraud risk factor 6.13 Hypothesis Testing

\section{First Main Hypothesis}

Multiple regression analysis was used to find out the role of Forensic Accounting Techniques in reducing Cloud Based Accounting risks in the Jordanian five stars hotels

\section{The main Hypothesis}

Ho: There is no statistically significant role of Forensic Accounting Techniques in reducing Cloud Based Accounting risks in the Jordanian five stars hotels 
Table (3)

The main Hypothesis test

\begin{tabular}{|l|l|l|l|l|}
\hline Model & R & R Square & F & Sig. \\
\hline 1 & .661 & .437 & 17.636 & .000 \\
\hline
\end{tabular}

Table (3) shows that the correlation coefficient ( $\mathrm{R})$ value is $=.661$ This means that there is a relationship between independent variables and the dependent one. $\mathrm{R}^{2}$ value is $=.437$ this means that $43.7 \%$ of variance in dependent variable is due to changes in independent variable. Table indicated that $F$ value $=17.636$ and Sig value is $(0.000)$ which is less than $(\alpha-0.05)$; this means that the null hypothesis is rejected and the alternative one is accepted. Therefore, there is a statistically significant role of Forensic Accounting Techniques in reducing Cloud Based Accounting risks in the Jordanian five stars hotels

Ho-1 There is no statistically significant role of (FPDDS) (Fraud prevention, detection and deterrence skills) in reducing Cloud Based Accounting risks in the Jordanian five stars hotels

Table (4)

\section{First hypothesis Tess}

\begin{tabular}{|l|l|l|l|l|l|}
\hline & \multicolumn{2}{|l|}{$\begin{array}{l}\text { Unstandardized } \\
\text { Coefficients }\end{array}$} & $\begin{array}{l}\text { Standardized } \\
\text { Coefficients }\end{array}$ & \multicolumn{2}{l|}{} \\
\hline Model & $\mathrm{B}$ & Std. Error & Beta & T & Sig. \\
\hline (Constant) & .721 & .377 & & 1.912 & .059 \\
\hline $\begin{array}{l}\text { FPDDS) (Fraud prevention, } \\
\text { detection and deterrence skills) }\end{array}$ & .814 & .096 & .660 & 8.517 & .000 \\
\hline
\end{tabular}

Table (4) shows regression coefficients (Beta) equal 0.660.And $\mathrm{t}=$ 8.517.at significant level $(0.000)$ the significance level for regression coefficient is less than $(\alpha=0.05)$, Therefore there is a statistically significant role of (FPDDS) (Fraud prevention, detection and deterrence skills) in reducing Cloud Based Accounting risks in the Jordanian five stars hotels
Ho-2 There is no statistically significant role of (FAIIS) (Forensic audit, investigation, and interviewing skills) in reducing Cloud Based Accounting risks in the Jordanian five stars hotels 
Table (5)

Second hypothesis Test

\begin{tabular}{|l|l|l|l|l|l|}
\hline & \multicolumn{2}{|l|}{$\begin{array}{l}\text { Unstandardized } \\
\text { Coefficients }\end{array}$} & $\begin{array}{l}\text { Standardized } \\
\text { Coefficients }\end{array}$ & \multicolumn{2}{l|}{} \\
\hline Model & B & Std. Error & Beta & T & Sig. \\
\hline (Constant) & 2.051 & .644 & & 3.184 & .002 \\
\hline $\begin{array}{l}\text { (FAIIS) (Forensic audit, investigation, } \\
\text { and interviewing skills) }\end{array}$ & .433 & .152 & .282 & 2.846 & .005 \\
\hline
\end{tabular}

Table (5) shows regression coefficients (Beta) equal $=0.282$.And $\mathrm{t}=2.846$.at significant level $(0.000)$ the significance level for regression coefficient is less than $(\alpha=0.05)$, Therefore , There is a statistically significant role of (FAIIS) (Forensic audit, investigation, and interviewing skills) in reducing Cloud Based Accounting risks in the Jordanian five stars hotels

Ho-3 There is no statistically significant role of (LMAS) (Litigation, mediation and arbitration skills) reducing Cloud Based Accounting risks in the Jordanian five stars hotels

Table (6)

\section{Regression coefficient for first hypothesis}

\begin{tabular}{|l|l|l|l|l|l|}
\hline & \multicolumn{2}{|l|}{$\begin{array}{l}\text { Unstandardized } \\
\text { Coefficients }\end{array}$} & $\begin{array}{l}\text { Standardized } \\
\text { Coefficients }\end{array}$ & \multicolumn{2}{l|}{} \\
\hline Model & $\mathrm{B}$ & Std. Error & Beta & T & Sig. \\
\hline (Constant) & 1.712 & .700 & & 2.447 & .016 \\
\hline $\begin{array}{l}\text { (LMAS) (Litigation, mediation } \\
\text { and arbitration skills) }\end{array}$ & .508 & .164 & .305 & 3.103 & .003 \\
\hline
\end{tabular}

Table (6) shows regression coefficients (Beta) equal $=0.305$. And $t=3.103$.at significant level $(0.000)$ the significance level for regression coefficient is less than $(\alpha=0.05)$, Therefore, There is a statistically significant role of (LMAS) (Litigation, mediation and arbitration skills) in reducing Cloud Based Accounting risks in the Jordanian five stars hotels
Ho-4 There is no statistically significant role of (CARDR) (Computer assisted reviews and document reviews) in reducing Cloud Based Accounting risks in the Jordanian five stars hotels 
Table (7)

\section{Fourth Test hypothesis}

\begin{tabular}{|l|l|l|l|l|l|}
\hline & \multicolumn{2}{|l|}{$\begin{array}{l}\text { Unstandardized } \\
\text { Coefficients }\end{array}$} & $\begin{array}{l}\text { Standardized } \\
\text { Coefficients }\end{array}$ & \multicolumn{2}{|l|}{} \\
\hline Model & B & Std. Error & Beta & T & Sig. \\
\hline (Constant) & 1.428 & .645 & & 2.212 & .029 \\
\hline $\begin{array}{l}\text { (CARDR) (Computer assisted } \\
\text { reviews and document reviews) }\end{array}$ & .597 & .156 & .366 & 3.815 & .000 \\
\hline
\end{tabular}

Table (7) shows regression coefficients (Beta) equal $=0.366$. And $\mathrm{t}=3.815$. at significant level $(0.000)$ the significance level for regression coefficient is less than $(\alpha=0.05)$, Therefore, there is a statistically significant role of (CARDR) (Computer assisted reviews and document reviews) in reducing Cloud Based Accounting risks in the Jordanian five stars hotels

\section{Conclusion and Recommendation}

The study concluded that all independent variables of forensic have high role in detecting fraud risk factor

-There is a statistically significant role of Forensic Accounting Techniques in reducing Cloud Based Accounting risks in the Jordanian five stars hotels

-There is statistically significant role of (FPDDS) (Fraud prevention, detection and deterrence skills) in reducing Cloud Based Accounting risks in the Jordanian five stars hotels

-There is a statistically significant role of (FAIIS) (Forensic audit, investigation, and interviewing skills) in reducing Cloud Based Accounting risks in the Jordanian five stars hotels

-Therefore, there is a statistically significant role of (LMAS) (Litigation, mediation and arbitration skills) in reducing Cloud Based Accounting risks in the Jordanian five stars hotels
-There is a statistically significant role of (CARDR) (Computer assisted reviews and document reviews) in reducing Cloud Based Accounting risks in the Jordanian five stars hotels

Based on the above-mentioned results, the study recommends the following:

Despite the fact that nature of computer crime is increasing daily, so there is a need for different types of efforts, to be made on all levels of cloud investigations. And in the same time all legislations and codification related to computer crimes must be updated and reviewed from time to time to keep up with emerging technology.

Jordan is a developing country, so Jordanian five-star hotels need to adopt the cloud accounting system for encouraging startups, generating employment and protecting the environment.

Jordanian five stars hotel should encourage accounting department in these hotels to carry out future studies on cloud computing. such studies must not be restricted only on theoretical aspect, but also should include empirical, for the purpose of finding out the real value of cloud computing in preventing financial fraud. 
References

[1]. Al Khalidi, S. H (2012), A proposed framework for judicial accountability and its role in discovering fraud .Financial, unpublished $\mathrm{PhD}$ thesis, University of Baghdad

[2]. Al Shetty. E. M. (2013) The possibility of Using Cloud computing Technique in ELearning in Qasim University. Working paper presented to the third International Elearning and distance Learning, Riyadh, Kingdom of Saudi Arabia

[3]. Bechtel, C., (2013) Cloud Computing and Forensic Accounting: Friends or Foes?). Available at SSRN: https://ssrn.com/abstract $=2218697$ or http://dx.doi.org/10.2139/ssrn.2218697

[4]. Bhasin, M. (2013). Survey of skills required by the forensic accountants: evidence from a developing country. International journal of contemporary business studies, vol:4, No:2.

[5]. Jamil,N. (2012), The Conceptual Framework for Judicial Accounting and the Requirements for its Application in the Iraqi Financial Environment . Unpublished MA thesis, University of Mosul,

[6]. Jones, S.., Zahir,I. , Uthayasanka, S. \&Peter E. D. (2017) Risks and rewards of cloud computing in the UK public sector:,A reflection on three Organizational case studies,

Springle

[7]. Kinkela, K., College I. (2013) Practical and ethical considerations on the use of cloud computing in accounting. Journal of Finance and Accountancy. Available at: http://www.aabri.com/manuscripts/131534.p $\underline{\mathrm{df}}$

[8]. Mell, P., and Grance, T., 2011: The NIST Definition of Cloud Computing (Draft). Recommendations of the National Institute for Standards and Technology, [online], NIST, http://csrc.nist.gov/publications/drafts/800145/Draft- SP-800-145 cloud-definition.pdf
[9]. Mohanty, A. \& Mishra, A. (2017) Benefits and Issues of Cloud Computing in Accounting. International Journal of Trend in Scientific Research and Development (IJTSRD), Vol.1, Issue 6

[10]. Muawwed, M.(2012) Cloud Computing in Libraries, Paper presented to Information Technology and communicatiob in Higer Education towardsactivcacating Cloud computing in Eugpet and its applications, Coferences Center at Cairo University, 15/7/2012

[11]. Popoola, O. M. J., Ahmad, A. C., \& Samsudin, R. S. (2014). Forensic Accounting Knowledge and Mindset on Task Performance Fraud Risk Assessment. International Journal of Business and Management, 9(9), 118.

[12]. Raihan, S. (2019) "The Concept of Cloud Accounting and its Adoption in Bangladesh" , International Journal of Trend in Scientific Research and Development Volume-3 , Issue-4,

[13]. Salunkhe, U. and Kelkar, S. (2016). A Study on the Scope of Cloud Computing in Management Education.AIMA Journal of Management \& Research, 10(2/4), pp.1-9

[14]. Sunday O. \& Okon E.(2013) ENSURING QUALITY CONTROL OF FORENSIC ACCOUNTING FOR EFFICIENT AND EFFECTIVE CORPORATE MANAGEMENT GLOBAL JOURNAL OF SOCIAL SCIENCES, VOL $12,27-33$

\section{Creative Commons Attribution License 4.0 (Attribution 4.0 International, CC BY 4.0)}

This article is published under the terms of the Creative Commons Attribution License 4.0 https://creativecommons.org/licenses/by/4.0/deed.en US 